\title{
THE CRUSTAL STRUCTURE OF DECEPTION ISLAND (WEST ANTARCTICA) BY GEOPHYSICAL DATA
}

\author{
S. Levashov ${ }^{1}$, I. Korchagin ${ }^{2}$, Yu. Kozlenko ${ }^{2}$, V. Solovyov ${ }^{2}$ \\ ${ }^{1}$ Institute of applied problems of Ecology, Geophysics and Geochemistry, Kyiv \\ ${ }^{2}$ Institute of Geophysics of National Academy of Science of Ukraine, Kyiv, valera@igph.kiev.ua
}

New results of the geophysical studies of deep inhomogeneities of crustal structures distribution that were obtained in the SW part of Bransfield Strait near the present Deception Island volcano are discussed.

The geophysical data interpretation suggests a local character of the present submarine volcanic activity in the SE part of Deception Island. The magma source is associated with a rather local tectonic disturbance at a depth above $6 \mathrm{~km}$. The formation and evolution of this disturbance may caused by features of the distribution of marginal tensions during the interaction of the tectonic continuation of the Hero Fracture Zone and the tectonic disturbances of Bransfield Strait Fracture Zone in the area of Deception Island.

\begin{abstract}
Дані електромагнітних зондувань, отримані під час сезонних робіт 9-ї Української антарктичної експедиції у внутрішній бухті о. Десепшн, виявили наявність значної області прогріву в кальдері неподалік від підводних вулканів у південносхідній частині острова. На глибинах 1,4-2,8 км можлива наявність інтрузивного тіла, яке створює джерело прогріву у верхній частині розрізу. Подібні тіла виявлені також у більш глибоких горизонтах. Джерело магми пов'язане із локальним тектонічним порушенням на глибині більше 6 км. Формування і розвиток цього порушення можуть бути обумовлені особливостями розподілу граничних напруг під час взаємодії тектонічного продовження зони розломів Хіро і тектонічних порушень рифтової зони протоки Брансфілд.
\end{abstract}

По данным электромагнитных зондирований, полученным во время сезонных работ 9-й Украинской антарктической экспедиции, во внутренней бухте о. Десепшн выявлена область прогрева, расположенная недалеко от цепочки подводных вулканов в юго-восточной части острова. На глубинах 1,4-2,8км предполагается наличие интрузивного тела, которое создает источник прогревания в верхней части разреза. Подобные тела выявлены и в более глубоких горизонтах.

\section{Introduction}

The geophysical observations made by the Institute of Geophysics NAS of Ukraine yielded new information for estimating the features of potential field anomalies distribution for structures of the West Antarctica aquatory (Drake Passage, Sea of Scotia, Bransfield Strait).

The results are of essential importance in solving both regional and local geological problems of the evolution of the West Antarctica region since the oceanic crust formation and evolution in the Bransfield Strait zone are genetically related with the tectonic plates subduction in the South Shetland Trough on the western coast of the Antarctic Peninsula.

Studies of the deep structure of Deception Island. Deception Island (fig. 1) is a stratovolcano completely formed in the postpleistocenic period via Bransfield Strait opening. It is a small above-water part of a submarine ridge $300 \mathrm{~km}$ long lying between the Isles Deception and Bridgman that were formed by active surface and submarine volcanic eruptions. The volcanic ridge is featured by present tectonic processes accompanied by intensive volcanic activity from Holocene to present on the Isles of Deception, Penguin and Bridgman.

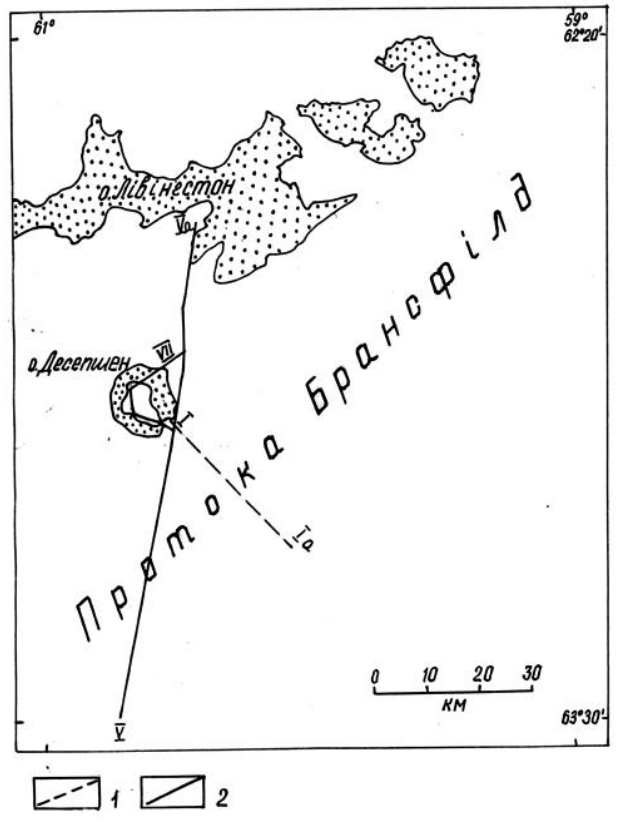

Fig. 1. Profiles of a geophysical survey made in Deception Island area. Legend: 1 - seismic profile [4]; 2 - VERS-profiles. 
Only for the last 200 years powerful eruptions on Deception Island occurred in 1842, 1912, 1917, 1967, 1969,1970 years. All they have resulted from general process of the geodynamic evolution of a new structure formed on the margin of the Bransfield rift zone $[3,4,5]$.

Deception Island forms a sigma-shaped mountain range striking $14 \mathrm{~km} \mathrm{NS}$ and $13 \mathrm{~km}$ EW. On the SE part of the Isle, a collapse of a part of caldera brought about a pass through which the inner zone with floor depths to $190 \mathrm{~m}$ was flooded.

The high activity of the recent volcanic processes is confirmed by the data of the glacial sediments stratigraphy and the presence of more than thirty craters situated over the whole perimeter of Deception Island composed mainly of volcanites and subdivided into segments by orthogonal fault systems (fig. 2).

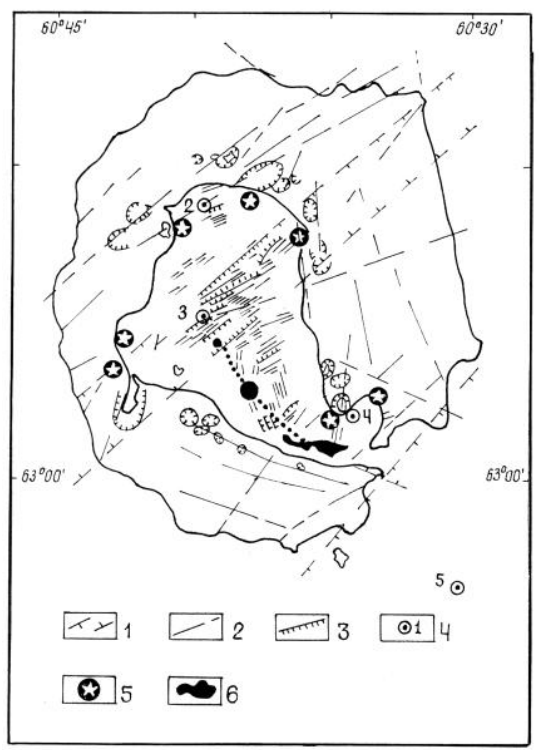

Fig. 2. Scheme of the structure of Deception Island, by [5]. Legend: $1-$ tectonic disturbances; 2 - faults; 3 - normal fault zones; 4 - electromagnetic sounding points [3]; 5 - volcanic slots; 6 - submarine volcanoes.

With the SE-NW fault system resent seismic activity manifestations are associated, it has bearing on the craters of volcanoes active in 1842, 1967 and 1970, as well as significant negative magnetic anomalies that may indicate the presence of molten masses at small depths. According to the aeromagnetic survey data, the amplitudes of the mapped local anomalies in Bransfield Strait attain $400 \mathrm{nT}$ over some volcanoes [5].

As known, the basalt lavas of the volcanoes contain much magnetic minerals that frequently change their magnetization at intensive local heating and gradual cooling. Therefore, the total magnetic effect of the bodies may serve as a peculiar indicator of predominating processes (piezomagnetic effect, thermal demagnetization, cooling in the magnetic field etc.) that characterize the physical state of a local body. The results of the studies made on the Isle of Deception in 1991 enabled to distinguish the anomalous volcanomagnetic effect of a local body, to calculate the approximate parameters and to localize it in space (fig. 3)-the intrusion is to $200 \mathrm{~m}$ thick and lies at depths from 500 to $1500 \mathrm{~m}[4,5]$.

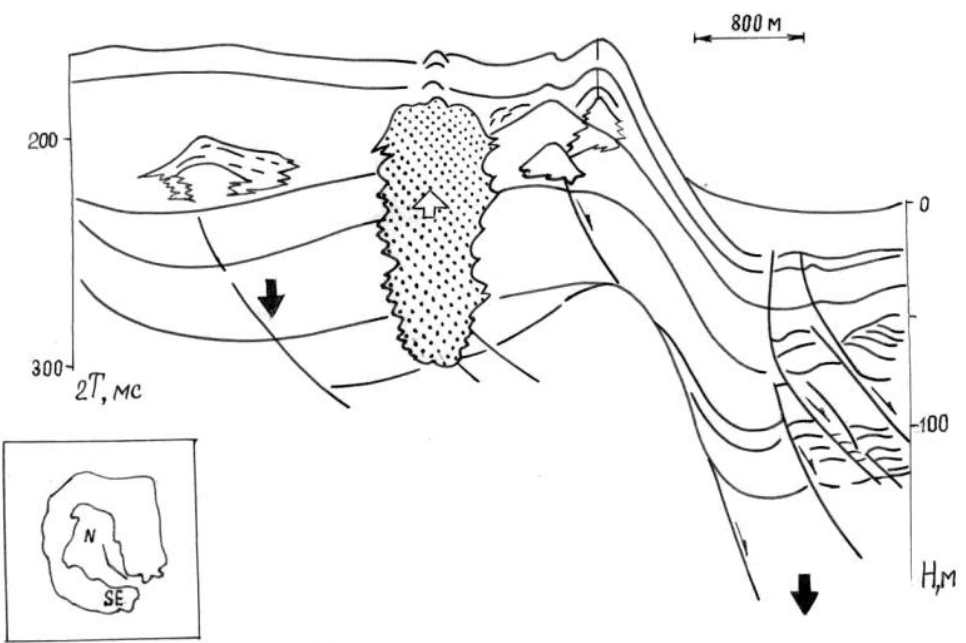

Fig. 3. Scheme of the deep structure of the volcano Deception [6]. The arrows show possible orientation of the slide of tectonic facies along fault zones. Shaded is a fluidsaturated body in the upper part of the section.

The results of the seismic studies of the inner bay of the Isle of Deception $[3,5]$ enable to distinguish in the upper part of the section three tectonostratigraphic groups $(\mathrm{A}, \mathrm{B}, \mathrm{C})$ genetically related with the formation of precaldera (A), syncaldera (B) and postcaldera (C) sedimentary facies with different seismic characteristics (fig. 3). The near-surface rocks are largely gas and fluid-saturated.

The seismic works of the last years show that the fault systems of the Isle of Deception have deep origin and may be spatially related with plate subduction processes in the South Shetland Trough area. The lower limit of the convection flows associated with possible deep magmas of the stationary or impulsive type remains unclear. 
A geochemical analysis of submarine and surface sediments of the Isle discovered clear regularities of the distribution of the most important elements ( $\mathrm{Fe}, \mathrm{Mn}, \mathrm{Na}, \mathrm{K}, \mathrm{Al}, \mathrm{Ca}$ ) associated with different stages of fault systems formation and peculiarities of tectonic evolution accompanied by the changes of the ratios of geochemical parameters of deep fluid flows. These characteristics also change along the submarine ridge axis and preserve transition values from typically oceanic to carbonate-alkali ones appropriate to trans-arc basins. These results also prove an absence of a relation of the elements of the investigated magma samples with the primary mantle surface; therefore it is reasonable to assume the presence of zones of intermediate crystallization of substances in lithosphere [1, 5].

The seismic information on the deep structure of the Isle of Deception is rather restricted since the lithospheric structure beneath the second layer $(\mathrm{V}=4.0-5.6 \mathrm{~km} / \mathrm{s})$ remains unknown. The basic rocks composing the predominant of deep sections are a volcanic ash with basalt fragments. The velocity values variation in rocks composing the upper part of the section is largely explained by the extent of volcanic rock compaction. The thick rock accumulations with comparatively low velocities $(1.8-2.3 \mathrm{~km} / \mathrm{s})$ are thought to be volcanic ash carried out by glaciers and surface water flows. The nonconsolidated and consolidated sediments in this area attain the total thickness of $2,5 \mathrm{~km}$.

By analogy with the adjacent parts of Bransfield Strait it may be assumed that the upper limit of rocks of the 3-d oceanic layer $(\mathrm{V}-6.6 \mathrm{~km} / \mathrm{s})$ lies at depths of $6.5-7.0 \mathrm{~km} / \mathrm{s}[3-6]$.

The electromagnetic sounding data obtained during the seasonal works of the $9^{\text {th }}$ Ukrainian Antarctic expedition in the inner bay of the Isle of Deception [2] detected a large heating zone in the caldera near the chain of submarine volcanoes in the SE part of the Island. Its central part formed by a single sinking block there may be an intrusive body at $1.4-2.8 \mathrm{~km}$ depth which may be a source of heat in the upper part of the section. Similar bodies were also detected at deeper horizons (fig. 5).

The shown three-layer structure of the section notably differs from the earlier published seismic data of the Isle (fig. 4). Possible cause of these differences may be the predominance of the present dense non-stratified and highvelocity basalts at depths up to $6.0-6.5 \mathrm{~km}$.

NW

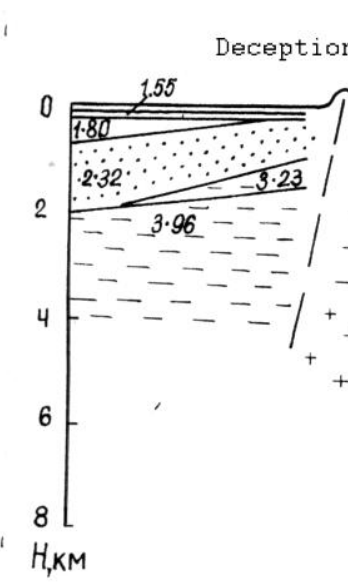

10

20

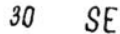

Fig. 4. Deep structure of the Deception Island [3]. Numbers show the velocity values in $\mathrm{km} / \mathrm{s}$. The seismic profile position is shown in Fig.1.

The data suggest a younger age for the NE-SW striking faults with which volcanic eruptions of the latest stages of magmatic evolution are associated. The meridionally striking faults are older, thus more ancient eruptions are associated with them [5].

The significant hydrothermal activity in Deception Island region, numerous craters on land, fumaroles and many submarine volcanoes in the SE part of the Isle evidence the large-scale magma sources and fluids situated at a great depth and genetically related not only with local but also with regional process of tectonic and geodynamic evolution of the region.

Detailed analysis of tectonic tensions shows that the chain of the submarine volcanoes of the Isle of Deception overlies a tectonic extensions structure while in the outer zone (Isle of Livingston area) compression structures stand out. Perhaps, the present dynamics of the SE- orientation of the Aluk (Phoenix) plate causes the formation and redistribution in time of the tectonic tension systems and magmatic activity manifestations in the western part of Bransfield Strait [1, 3-5]. 


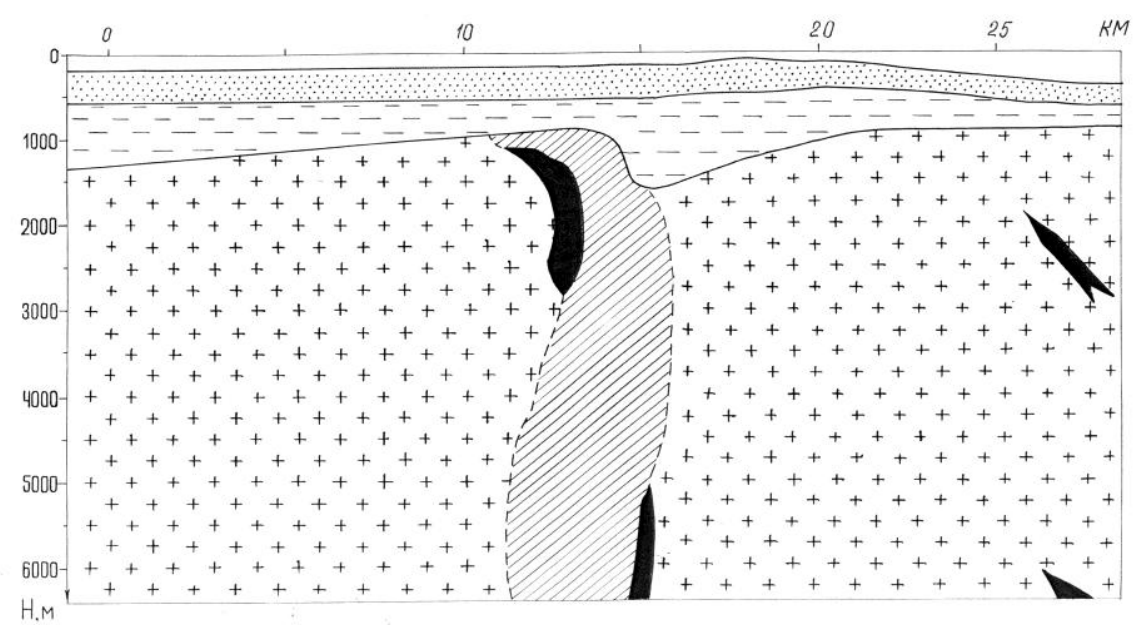

Fig. 5. The results of the interpretation of electromagnetic sounding data of Deception Island and Bransfield Strait (the profiles VII-VIIa and V-Va [2]). Legend: 1 - sediments; 2 - rocks of the second oceanic layer; 3 - rocks of the 3-d oceanic layer; 4 - zones of heating and fragmented rocks; 5 - dikes. The profile position is shown in Fig.1.

Conclusion. The geophysical data interpretation suggests a local character of the present submarine volcanic activity in the SE part of Deception Island. The magma source is associated with a rather local tectonic disturbance with a depth above $6 \mathrm{~km}$. The formation and evolution of this disturbance may caused by features of the distribution of marginal tensions during the interaction of the tectonic continuation of the Hero Fracture Zone and tectonic disturbances of Bransfield Strait Fracture Zone.

\section{References}

1. Бахмутов В.Г., Козленко Ю.В., Корчагин И.Н., Орлова М.И., Соловьев В.Д., Шепель С.И., Якимчук Н.А., Якимчук Ю.Н. Геофизические исследования в Украинских морских антарктических экспедициях (по материалам 60 и 61-го рейсов НИС «Эрнст Крендель») // Ин-т геофизики НАН Украины. - Киев, 2001. - 323 с. - Деп. в ГНТБ Украины 9.04.2001. - № 70-Ук2001.

2. Левашов С.П., Песчаный Ю.М. Картографические материалы результатов геоэлектрических работ в районе Антарктического полуострова. Материалы IX Украинской Антарктической экспедиции. Киев. - 2004.

3. Ashcroft W.A. Crustal structure of the South Shetland Islands and the Bransfield Strait. - British Antarctic Survey Scientific Reports. 1972, 66: 1-43.

4. Barker D.H.N., Austin J.A. 1998. Rift propagation, detachment faulting and associated magnetism in Bransfield Strait, Antarctic Heninsula. - Journal of Geophysical Research, 103 (B10): 24017-24043.

5. J.Rey, L.Somoza, J.Martinez-Frias Evidencias tectonicas, volcanicas e hidrotemales en isla Decepcion, relacionadas con el marco geodinamico de la cuenca de Bransfield(Antartida). Actas del V simposio Espanol de estudios Antarticos. 1991,.p. 209-221. 